\title{
Phenotypic Variation of Fluoride Responses between Inbred Strains of Mice
}

\author{
Dong Yan ${ }^{a}$ Thomas L. Willett ${ }^{\mathrm{e}}$ Xiao-Mei Gu ${ }^{\mathrm{b}} \quad$ E. Angeles Martinez-Mier ${ }^{\mathrm{d}}$ \\ Laura Sardone $^{\mathrm{e}}$ Lauren McShane ${ }^{\mathrm{e}}$ Marc Grynpas ${ }^{\mathrm{e}}$ Eric T. Everett ${ }^{\mathrm{c}}$ \\ ${ }^{a}$ Dental Research, ${ }^{b}$ Oral Biology Curriculum, and ${ }^{\mathrm{c} P e d i a t r i c}$ Dentistry and The Carolina Center for Genome Science, \\ University of North Carolina at Chapel Hill, Chapel Hill, N.C., and Preventive and Community Dentistry, \\ Oral Health Research Institute, Indiana University School of Dentistry, Indianapolis, Ind., USA; \\ 'Bone Biology Laboratory, Samuel Lunenfeld Research Institute, Mount Sinai Hospital, Toronto, Ont., Canada
}

\section{Key Words}

Fluoride $\cdot$ Fluorosis $\cdot$ Genetics $\cdot$ Bone $\cdot$ Teeth

\begin{abstract}
Excessive systemic exposure to fluoride $(F)$ can lead to disturbances in bone homeostasis and dental enamel development. We have previously shown strain-specific responses to $\mathrm{F}$ in the development of dental fluorosis (DF) and in bone formation/mineralization. The current study was undertaken to further investigate $F$ responsive variations in bone metabolism and to determine possible relationships with DF susceptibility. Seven-week-old male mice from FVB/NJ, C57BL/6J, C3H/HeJ, A/J, 129S1/SvImJ, AKR/J, DBA/2J, and $\mathrm{BALB} / \mathrm{cBy}$ j inbred strains were exposed to $\mathrm{NaF}(0$ or $50 \mathrm{ppm}$ as $\left.F^{-}\right)$in drinking water for 60 days. Sera were collected for $F$, $\mathrm{Ca}, \mathrm{Mg}_{1} \mathrm{PO}_{4}, \mathrm{iPTH}$, sRANKL, and ALP levels. Bone marrow cells were subjected to ex vivo cell culture for osteoclast potential and CFU colony assays (CFU-fibroblast, CFU-osteoblast, CFUerythrocyte/granulocyte/macrophage/megakaryocyte, CFU-granulocyte/macrophage, CFU-macrophage, and CFUgranulocyte). Femurs and vertebrae were subjected to micro-CT analyses, biomechanical testing, and F, Mg, and $\mathrm{Ca}$ content assays. DF was evaluated using quantitative fluorescence and clinical criteria. Strain-specific responses to $F$ were observed for DF, serum studies, ex vivo cell culture studies, and bone quality. Among the strains, there were no patterns
\end{abstract}

or significant correlations between DF severity and the actions of $\mathrm{F}$ on bone homeostasis (serum studies, ex vivo assays, or bone quality parameters). The genetic background continues to play a role in the actions of $\mathrm{F}$ on tooth enamel development and bone homeostasis. F exposure led to variable phenotypic responses between strains involving dental enamel development and bone metabolism.

Copyright $\odot 2011$ S. Karger AG, Base

\section{Introduction}

Excessive systemic exposure to fluoride (F) can lead to disturbances in bone homeostasis and amelogenesis [Everett, 2010]. The latter results in dental fluorosis (DF) [Bronckers et al., 2009]. An individual's genetic background is a factor in DF susceptibility [Everett et al., 2002; Vieira et al., 2005a; Carvalho et al., 2009]. The genetic background also plays a role in the actions of $\mathrm{F}$ on bone and bone cells [Mousny et al., 2006; Yan et al., 2007; Chou et al., 2009]. The relationship between DF susceptibility and the effects on bone and bone cells is not well understood. The goal of this study was to investigate the range of responses to $\mathrm{F}$ across several inbred strains of mice and to determine any relationship between DF susceptibility and the actions of $\mathrm{F}$ on bone homeostasis.

\section{KARGER}

() 2011 S. Karger AG, Basel

Fax +4161306 1234

E-Mail karger@karger.ch

www.karger.com
Accessible online at: www.karger.com/cto
Prof. Eric T. Everett, Department of Pediatric Dentistry

School of Dentistry and The Carolina Center for Genome Sciences

University of North Carolina at Chapel Hill

228 Brauer Hall, CB \#7450, Chapel Hill, NC 27599-7450 (USA)

Tel. +1 919966 4588, E-Mail eric_everett@dentistry.unc.edu 


\begin{tabular}{llll}
\hline \multicolumn{2}{l}{ Abbreviations used in this paper } & & \\
\hline ALP & total alkaline phosphatase & $\mathrm{EIA}$ & enzyme immunoassay \\
$\mathrm{A} / \mathrm{P}$ & anterior posterior & $\mathrm{F}$ & fluoride \\
$\mathrm{BMC}$ & bone marrow cell & $\mathrm{F}_{\mathrm{u}}$ & ultimate load \\
$\mathrm{BMD}$ & bone mineral density & $\mathrm{iPTH}$ & intact parathyroid hormone \\
$\mathrm{BS}$ & bone surface & $\mathrm{Mg}$ & magnesium \\
$\mathrm{BV}$ & bone volume & $\mathrm{M} / \mathrm{L}$ & medial lateral \\
Ca & calcium & $\mathrm{NaF}$ & sodium fluoride \\
CFC & hematopoietic colony-forming cell & $\mathrm{OC}$ & osteoclast potential \\
CFU & colony-forming unit & $\mathrm{PO}$ & phosphate \\
CFU-F & colony-forming unit-fibroblast & $\mathrm{QF}$ & quantitative fluorescence \\
CFU-G & colony-forming unit-granulocyte & $\mathrm{S}$ & bending stiffness \\
CFU-GEMM & colony-forming unit-granulocyte/erythrocyte/ & $\mathrm{sRANKL}$ & soluble receptor activator of nuclear factor \\
& macrophage/megakaryocyte & & (NF)- $\mathrm{B}$ ligand \\
CFU-GM & colony-forming unit-macrophage & TRAP & tartrate-resistant acid phosphatase \\
CFU-M & colony-forming unit-monocyte/macrophage & TV & tissue volume \\
CFU-OB & colony-forming unit-osteoblast & $\mathrm{U}_{\mathrm{f}}$ & energy to failure \\
DF & dental fluorosis & $\mathrm{US}$ & ultimate stress \\
E & elastic modulus & & \\
\hline
\end{tabular}

\section{Animals and Methods}

Animals

Male mice from FVB/NJ (FVB), C57BL/6J (B6), C3H/HeJ (C3H), A/J, 129S1/SvImJ (129S1), AKR/J (AKR), DBA/2J (DBA), and $\mathrm{BALB} / \mathrm{cByJ}$ (BALB) inbred strains were obtained from The Jackson Laboratory (Bar Harbor, Me., USA) at 6 weeks of age and were acclimated for 1 week prior to treatment with sodium $F$ $(\mathrm{NaF}) . \mathrm{NaF}$ was provided in drinking water at concentrations of 0 or $50 \mathrm{ppm} \mathrm{F}^{-}$for 60 days. Each treatment/control group consisted of 6 mice. All animals were housed in the Division of Lab Animal Medicine facility within the Dental Research Center at the University of North Carolina at Chapel Hill (a fully AAALACaccredited unit). Mice were fed a constant sustenance of LabDiet ${ }^{\circledR}$ $5001\left(\mathrm{PMI}^{\circledR}\right.$ Nutrition International) containing $0.95 \%$ calcium (Ca), $0.66 \%$ phosphate $\left(\mathrm{PO}_{4}\right), 4.5 \mathrm{IU} / \mathrm{g}$ vitamin $\mathrm{D}_{3}$, and an average $[\mathrm{F}]$ of $6.56 \pm 0.28 \mu \mathrm{g} / \mathrm{g}$, and they were allowed food and water ad libitum. Animal studies were approved by the Institutional Animal Care and Use Committee of the University of North Carolina at Chapel Hill.

\section{DF Phenotyping}

The lower incisors were assessed for DF severity. Clinical criteria (modified TF scale) and quantitative fluorescence (QF) were used to measure the severity of DF in mice [Everett et al., 2002; Carvalho et al., 2009; Everett, 2010].

\section{Serum and Bone Chemistry Assays}

Sera were subjected to total alkaline phosphatase (ALP), Ca, $\mathrm{PO}_{4}$, magnesium $(\mathrm{Mg})$, and $\mathrm{F}$ determinations as previously described [Yan et al., 2007]. The proximal ends of the mouse left femurs were used for elemental analysis. Instrumental neutron activation analysis (INAA) was used to quantify $\mathrm{F}, \mathrm{Mg}$, and $\mathrm{Ca}$ in bone [Mousny et al., 2006].

\section{Serum Enzyme Immunoassay}

Sera were subjected to enzyme immunoassays (EIAs) for the bone metabolism markers intact parathyroid hormone (iPTH) (mouse) EIA (ALPCO Diagnostics, Salem, N.H., USA) and soluble receptor activator of nuclear factor (NF)- $\kappa$ B ligand (sRANKL) mouse/rat EIA (ALPCO Diagnostics) as previously described [Yan et al., 2007].

\section{Bone Marrow Cell Cultures}

Osteoclast potential (OC), hematopoietic colony-forming cells (CFC) [colony-forming unit-granulocyte/erythrocyte/macrophage/megakaryocyte (CFU-GEMM), CFU-macrophage (CFUGM), CFU-monocyte/macrophage (CFU-M), and CFU-granulocyte (CFU-G)], CFU-F, and CFU-OB assays were performed as previously described [Yan et al., 2007; Chou et al., 2009].

\section{$\mu C T$ Analysis}

Static histomorphometry was performed on L4/L5 vertebrae and femurs using a Skyscan 1074HR micro-CT (Skyscan, Aartselaar, Belgium) at a resolution of $20.5 \mu \mathrm{m} /$ pixel. Standardized scanning and image reconstruction settings were used. Hydroxyapatite phantoms $\left(250\right.$ and $750 \mathrm{mg} / \mathrm{cm}^{3}$ ) (CIRS, Inc., Norfolk, Va., USA) were used in order to determine bone mineral densities (BMD) within regions and volumes of interest. The microarchitecture was as follows: bone volume (BV)/tissue volume (TV) (\%), bone surface (BS)/BV $\left(\mathrm{mm}^{-1}\right)$, trabecular thickness $(\mathrm{mm})$, trabecular separation $(\mathrm{mm})$, trabecular number $\left(\mathrm{mm}^{-1}\right)$, medial lateral $(\mathrm{M} / \mathrm{L})$ diameter $(\mathrm{mm})$, anterior posterior $(\mathrm{A} / \mathrm{P})$ diameter $(\mathrm{mm})$, and cortical thickness ( $\mathrm{mm}$ ) were calculated using 3-D-based volume models or 2-D cross-sectional images through $\mu \mathrm{CT}$ analysis including the trabecular region of L4/L5 vertebrae and a 1-mm cortical region within the mid-diaphysis of the femurs as previously described [Yan et al., 2007]. 
Fig. 1. a, b The severity of DF was categorized using clinical criteria and QF. a Lower incisors assessed using the modified TF scale for DF. b QF analysis of DF in lower incisors. c Serum $[\mathrm{F}](\mu \mathrm{M})$ between inbred strains and $\mathrm{F}$ treatment. $\mathbf{d}$ Bone $[\mathrm{F}]$ content (ppm) between inbred strains and $\mathrm{F}$ treatment. $\mathrm{n}=4-6{ }^{*} \mathrm{p} \leq 0.05$ and ${ }^{* *} \mathrm{p} \leq 0.001$ comparing treated and untreated groups within each strain.

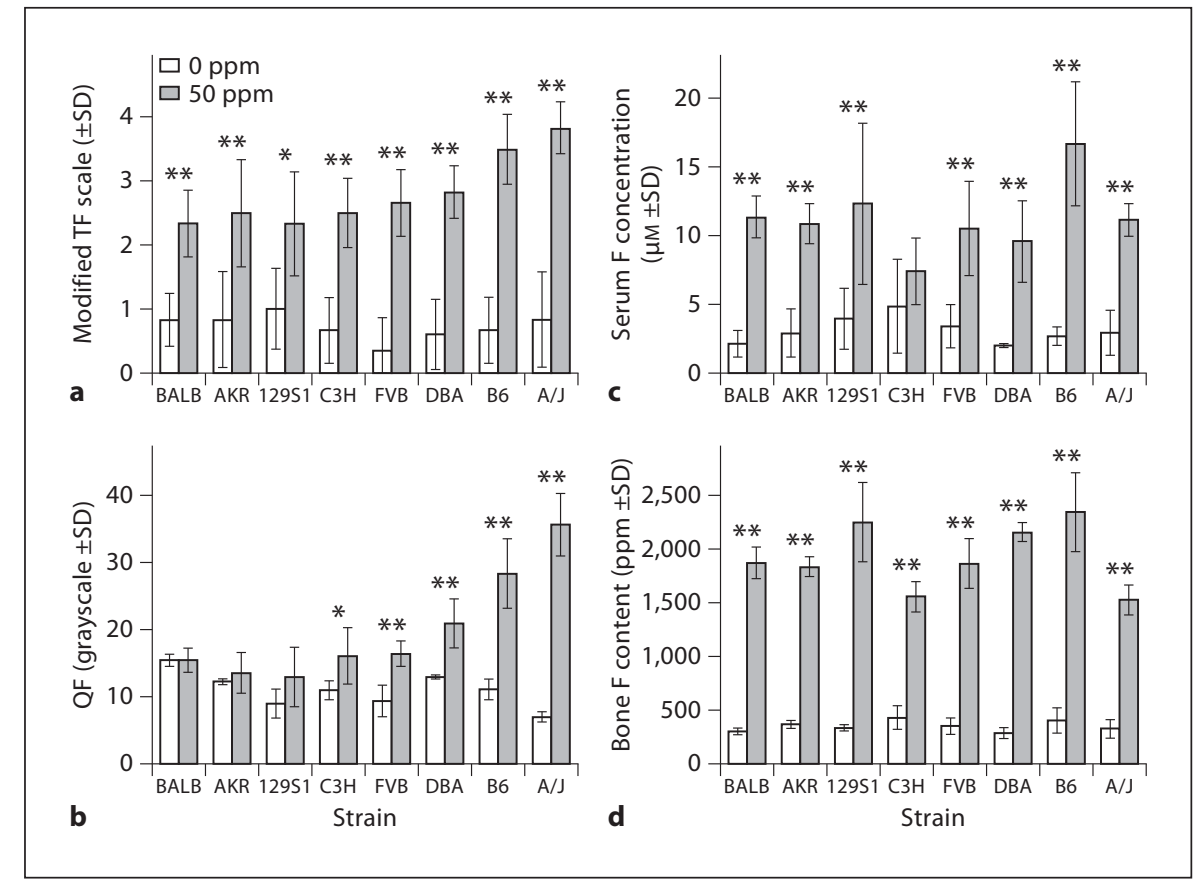

\section{Mechanical Testing}

Three-point bending (mid-shaft left femur) and vertebral compression (5th lumbar vertebrae) tests were performed as previously described [Mousny et al., 2006]. The structural, material, and geometric parameters were determined from the acquired load-displacement data, the load-deformation curve, cross section data, and stress-strain data.

\section{Statistic Analysis}

SPSS version 15.0 (SPSS Inc., Chicago, Ill., USA) was used to perform statistical analyses on all parameters. Statistical analyses were performed using 2-way ANOVA to compare results between the 8 genetic strains and the 2 treatment groups, and the Bonferroni test was used post hoc. $\mathrm{p} \leq 0.05$ was considered statistically significant.

\section{Results}

\section{DF Evaluation}

All strains developed DF following F treatment. The severity of DF showed strain-specific responses (fig. 1a, b). While baseline clinical scores did not differ between strains $(\mathrm{p}=0.55)$, baseline QF did $(\mathrm{p}<0.001)$. BALB had the highest baseline $\mathrm{QF}$ among strains. Compared to baseline ( 0 ppm F), the greatest increases in $\mathrm{QF}$ values or the severity of DF were observed in A/J $(417 \%, \mathrm{p}<0.001)$ and B6 (157\%, p < 0.001); modest increases were observed in FVB $(76 \%, \mathrm{p}<0.001)$, DBA $(62 \%, \mathrm{p}=0.001)$, and $\mathrm{C} 3 \mathrm{H}$
(47\%, $\mathrm{p}=0.017)$, and small increases were found in $129 \mathrm{~S} 1$ $(45 \%, \mathrm{p}=0.071), \operatorname{AKR}(10 \%, \mathrm{p}=0.334)$, and BALB $(<1 \%$, $\mathrm{p}=0.893)$. The mean value differences with $\mathrm{p}>0.05$ are not statistically significant. Among the 8 strains investigated, A/J and B6 are the most susceptible to developing DF. 129S1, AKR, and BALB are the most resistant to DF.

\section{Serum Chemistries and Bone Elemental Analyses}

At baseline, serum $\mathrm{F}$ was not significantly different between all strains $(\mathrm{p}=0.403)$, whereas bone F did significantly differ $(p=0.03)$. Serum and bone $[F]$ increased in all strains following $\mathrm{F}$ exposure although differences between treated and control groups within and among strains differed greatly (fig. 1c, d). For serum $\mathrm{F}$ in $\mathrm{C} 3 \mathrm{H}$ there was no significant difference between 0 and $50 \mathrm{ppm}$ $\mathrm{F}(\mathrm{p}=0.194)$. The largest differences were observed in B6 (increase of $518 \%, \mathrm{p}<0.001$ over baseline). At 50 ppm F, serum $[F]$ was not significantly different $(p=1.000)$ between BALB (DF-resistant) and A/J (DF-susceptible) strains. All strains showed significant increases in bone [F] over baseline following $\mathrm{F}$ exposure. B6 demonstrated the largest increase $(481 \%, \mathrm{p}<0.001)$ in bone $\mathrm{F}$ between 0 - and 50 -ppm treatments, whereas the increase in $\mathrm{C} 3 \mathrm{H}$ (261\%, p < 0.001) was the least among the strains investigated. At 50 ppm F, bone [F] was not significantly different $(p=0.599)$ between BALB (DF-resistant) and A/J (DF-susceptible) strains. There were no significant dif- 

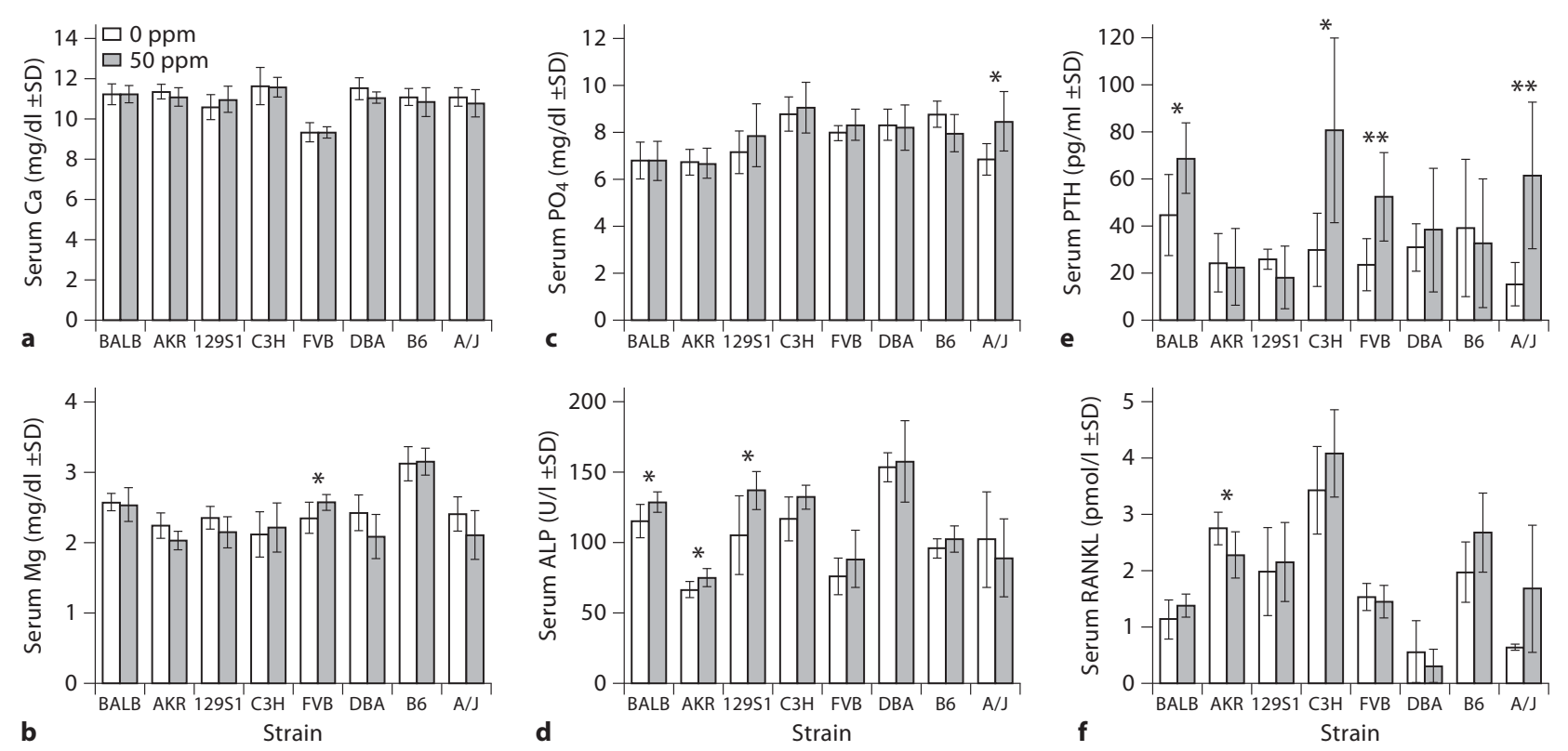

Fig. 2. Serum $\mathrm{Ca}, \mathrm{Mg}, \mathrm{PO}_{4}, \mathrm{ALP}, \mathrm{iPTH}$, and sRANKL between strains and $\mathrm{F}$ treatment groups. $\mathrm{n}=6$; $^{*} \mathrm{p} \leq 0.05$ and ${ }^{* *} \mathrm{p} \leq 0.001$ comparing treated and untreated groups within each strain.

ferences in serum $[\mathrm{F}]$ or bone $[\mathrm{F}]$ between both strains at baseline $(0 \mathrm{ppm})$. F treatment did not alter bone $\mathrm{Mg}$ or $\mathrm{Ca}$ levels for any strain (data not shown). At baseline serum $\mathrm{Ca}, \mathrm{Mg}, \mathrm{PO}_{4}$, and ALP significantly differed between strains $(\mathrm{p}<0.001)$. No significant differences were observed in serum $\mathrm{Ca}$ between the 0 - and 50-ppm treatments for each strain. Serum $\mathrm{PO}_{4}$ was modestly elevated over baseline only in $\mathrm{A} / \mathrm{J}$ mice $(24 \%, \mathrm{p}=0.018)$. Serum $\mathrm{Mg}$ was mildly elevated over baseline only in the FVB strain $(10 \%, \mathrm{p}=0.043)$. Serum total ALP showed significant increases over baseline following $\mathrm{F}$ treatment in 3 strains: $129 \mathrm{~S} 1(31 \%, \mathrm{p}=0.029), \mathrm{AKR}(13 \%, \mathrm{p}=0.032)$, and BALB $(11 \%, \mathrm{p}=0.041)$.

\section{Serum ELISA/EIA}

Significant differences in baseline iPTH $(\mathrm{p}=0.05)$ and sRANKL $(\mathrm{p}<0.001)$ levels were observed between strains. Even though $\mathrm{iPTH}$ showed a wide range in mean values (15.1-44.6 pg/ml) it also demonstrated the greatest variance with SD ranging from 4.2 to $29.1 \mathrm{pg} / \mathrm{ml}$. Following $\mathrm{F}$ treatment iPTH significantly increased in BALB (54.43\%, $\mathrm{p}=0.027), \mathrm{FVB}(123.66 \%, \mathrm{p}=0.008), \mathrm{C} 3 \mathrm{H}$ $(171.47 \%, p=0.014)$, and $A / J(308.55 \%, p=0.006)$ (fig. 2e), whereas sRANKL decreased only in 1 strain, AKR $(-17.39 \%, p=0.04)$ (fig. 2f).

\section{Ex vivo Cell Cultures}

Ex vivo cell culture studies included CFU-F assays, ex vivo OC, and CFC assays. A wide range of interstrain variation for OC, CFC (CFU-GEMM and CFU-GM), and $\mathrm{CFU}-\mathrm{F}(\mathrm{OB})$ assays existed at baseline $(\mathrm{p}<0.001)$. Among the strains the greatest differences in baseline OC were between 129S1 [70/1 $\times 10^{5}$ bone marrow cells $\left.(\mathrm{BMC})\right]$ and $\mathrm{A} / \mathrm{J}\left(541 / 1 \times 10^{5} \mathrm{BMC}\right)$. Strain-specific responses to $F$ were observed in all ex vivo cell culture studies (fig. 3 ). Following F exposure, total CFU-F (ALP-positive) colonies increased over baseline only in the FVB strain $(43 \%$, $\mathrm{p}=0.026$ ), while the ratio of ALP-positive colonies to all CFU-F colonies increased in FVB $(22 \%, \mathrm{p}<0.001)$ and $\mathrm{C} 3 \mathrm{H}(15 \%, \mathrm{p}=0.018)$. OC [tartrate-resistant acid phosphatase (TRAP)-positive cells with $\geq 3$ nuclei] increased in $\mathrm{A} / \mathrm{J}(14 \%, \mathrm{p}=0.001)$ and $129 \mathrm{~S} 1(84 \%, \mathrm{p}<0.001)$ (fig. 3c). CFU-GEMM colonies increased in A/J $(20 \%, \mathrm{p}=0.039)$ and DBA (42\%, p < 0.001) (fig. 3d). CFU-GM colonies showed an increase in FVB $(21 \%, \mathrm{p}=0.034)$ and DBA $(30 \%, p=0.044)$ (fig. 3e).

\section{Bone $\mu \mathrm{CT}$ Analyses}

$F$ treatment had no significant effect on trabecular bone (vertebrae) microarchitecture (BV/TV, BS/BV, trabecular thickness, trabecular separation, or trabecular 

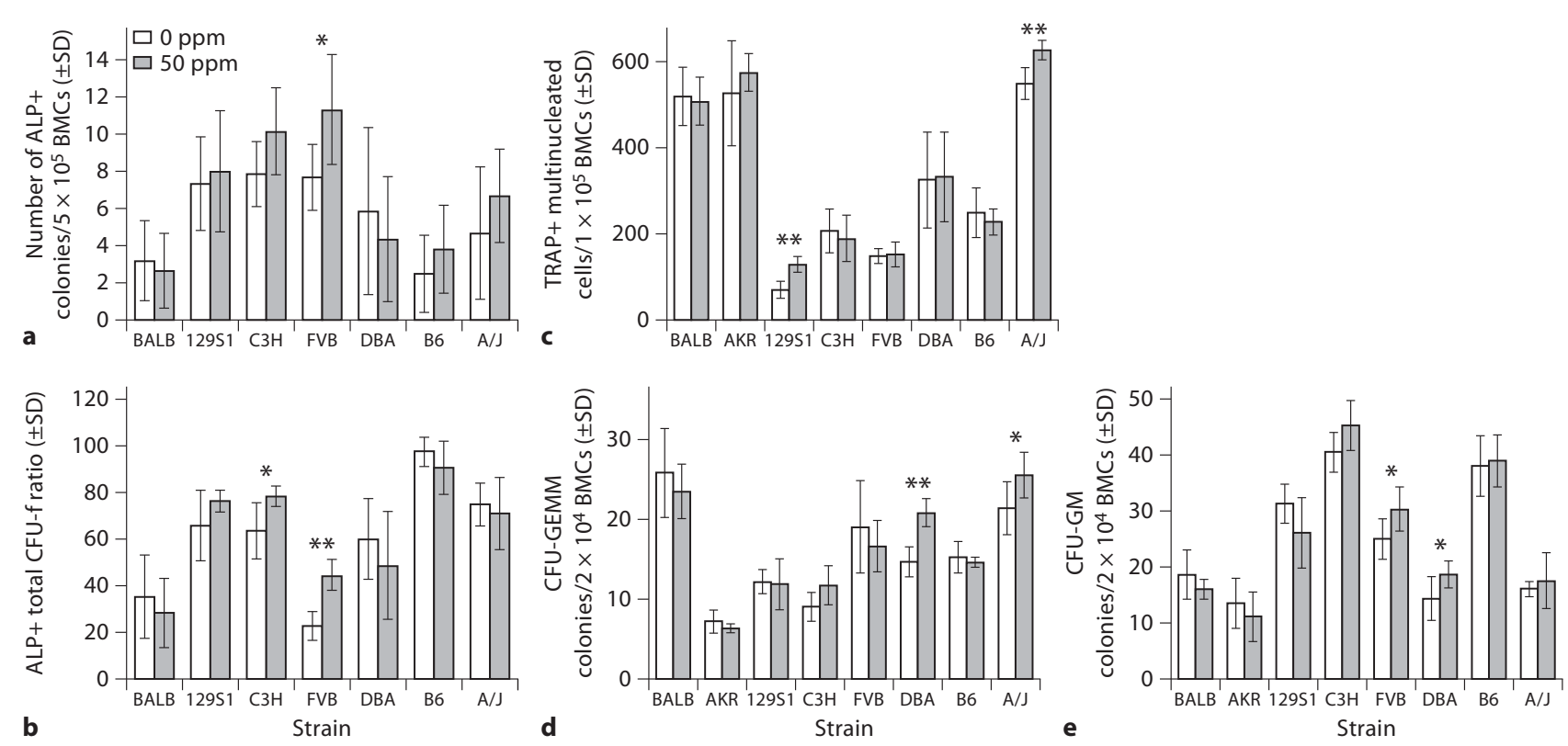

Fig. 3. Ex vivo BMC cultures. BMCs were cultured in osteogenic media to count the number of ALP-positive colonies $/ 5 \times 10^{5}$ BMCs (a) and the ratio of ALP-positive to total CFU-F colonies (b). OC, BMCs treated with mCSF and sRANKL and TRAP-positive cells with $\geq 3$ nuclei counted as osteoclasts $/ 1 \times 10^{5}$ cells (c). CFUGEMM and CFU-GM colonies $/ 2 \times 10^{4} \operatorname{BMCs}(\mathbf{d}, \mathbf{e}) \cdot \mathrm{n}=6-8 ;{ }^{*} \mathrm{p} \leq 0.05$ and ${ }^{* *} \mathrm{p} \leq 0.001$ between treated and untreated groups in each strain.

number) or BMD among the strains investigated. For cortical bone the $\mathrm{M} / \mathrm{L}$ and $\mathrm{A} / \mathrm{P}$ diameters were increased following $\mathrm{F}$ treatment in only 1 strain, i.e. 129S1, (M/L diameter: 0 ppm $1.31 \pm 0.09 \mathrm{~mm}, 50$ ppm $1.77 \pm 0.10$ $\mathrm{mm}, \mathrm{p}=0.001 ; \mathrm{A} / \mathrm{P}$ diameter: $0 \mathrm{ppm} 0.95 \pm 0.06 \mathrm{~mm}, 50$ ppm $1.24 \pm 0.06 \mathrm{~mm}, \mathrm{p}=0.002$ ). This increase in midshaft dimension was not accompanied by changes in cortical thickness or cortical BMD.

\section{Bone Mechanical Testing (Structural and Material Properties) \\ Cortical Bone}

Three-point bending tests were performed on the left femur of each mouse to assess cortical bone quality. The structural properties of 4 out of 8 strains $(\mathrm{B} 6, \mathrm{C} 3 \mathrm{H}, \mathrm{DBA}$, and AKR) were affected by the 50-ppm F treatment compared to 0-ppm controls. DBA [ultimate load $\left(\mathrm{F}_{\mathrm{u}}\right): 0 \mathrm{ppm}$ $21.6 \pm 1.4 \mathrm{~N}, 50 \mathrm{ppm} 16.8 \pm 1.6 \mathrm{~N}, \mathrm{p}=0.007$; bending stiffness (S): $0 \mathrm{ppm} 184 \pm 24 \mathrm{~N} / \mathrm{mm}, 50 \mathrm{ppm} 150 \pm 6 \mathrm{~N} /$ $\mathrm{mm}, \mathrm{p}=0.026]$ and AKR $\left(\mathrm{F}_{\mathrm{u}}: 0 \mathrm{ppm} 30.8 \pm 3.6 \mathrm{~N}, 50\right.$ ppm $22.8 \pm 4.8 \mathrm{~N}, \mathrm{p}<0.001$; S: 0 ppm $230 \pm 14 \mathrm{~N} / \mathrm{mm}$, $50 \mathrm{ppm} 179 \pm 49 \mathrm{~N} / \mathrm{mm}, \mathrm{p}<0.001)$ showed significant decreases in $\mathrm{F}_{\mathrm{u}}$ and $\mathrm{S}$ at $50 \mathrm{ppm}$ compared to the 0-ppm treatment group. $\mathrm{B} 6$ [energy to failure $\left(\mathrm{U}_{\mathrm{f}}\right): 0 \mathrm{ppm} 8.4 \pm$ $5.5 \mathrm{~mJ}, 50 \mathrm{ppm} 5.0 \pm 1.8 \mathrm{~mJ}, \mathrm{p}=0.023)]$ and $\mathrm{C} 3 \mathrm{H}\left(\mathrm{U}_{\mathrm{f}}: 0\right.$ ppm $14.46 \pm 1.7 \mathrm{~mJ}, 50 \mathrm{ppm} 11.40 \pm 4.9 \mathrm{~mJ}, \mathrm{p}=0.042$ ) both showed a decrease in $\mathrm{U}_{\mathrm{f}}$ at $50 \mathrm{ppm}$ relative to the 0 -ppm controls. The other 4 strains showed no significant difference in bone structural properties between the 0 - and $50-\mathrm{ppm} \mathrm{F}$ treatments. The material properties of 5 out of 8 strains (129S1, B6, C3H, DBA, and AKR) were differentially affected by the 50-ppm $\mathrm{F}$ treatment compared to 0 -ppm controls. Treatment with $50 \mathrm{ppm} F$ resulted in decreased ultimate stress (US) and elastic modulus (E) in 129S1 (US: 0 ppm $242.42 \pm 19.08 \mathrm{MPa}$, 50 ppm $187.15 \pm 15.69 \mathrm{MPa}, \mathrm{p}<0.05$; E: 0 ppm $0.10 \pm$ $0.01 \mathrm{GPa}, 50 \mathrm{ppm} 0.07 \pm 0.01 \mathrm{GPa}, \mathrm{p}<0.05)$, decreased US in AKR $(0$ ppm $235.82 \pm 22.22 \mathrm{MPa}, 50$ ppm 168.80 $\pm 40.66 \mathrm{MPa}, \mathrm{p}<0.05)$, decreased yield stress in DBA $(0 \mathrm{ppm} 242.72 \pm 20.69 \mathrm{MPa}, 50 \mathrm{ppm} 197.00 \pm 63.80$ $\mathrm{MPa}, \mathrm{p}<0.05)$, increased yield strain in B6 (0 ppm 1.71 $\pm 0.04 \%, 50 \mathrm{ppm} 2.09 \pm 0.28 \%, \mathrm{p}<0.05)$, and decreased toughness in $\mathrm{C} 3 \mathrm{H}\left(0 \mathrm{ppm} 23.36 \pm 7.07 \mathrm{~mJ} / \mathrm{mm}^{3}, 50 \mathrm{ppm}\right.$ $\left.16.25 \pm 5.53 \mathrm{~mJ} / \mathrm{mm}^{3}, \mathrm{p}<0.05\right)$. 
Vertebral Trabecular Bone

Compression testing was used to evaluate the lattice network of vertebral trabecular bone. The structural properties of the vertebrae in the BALB, 129S1, FVB, B6, and $\mathrm{A} / \mathrm{J}$ strains changed variably due to $\mathrm{F}$ exposure. Following $\mathrm{F}$ exposure, FVB demonstrated significant decreases in $\mathrm{F}_{\mathrm{u}}(0 \mathrm{ppm} 32.30 \pm 2.21 \mathrm{~N}, 50 \mathrm{ppm} 20.75 \pm$ $5.2 \mathrm{~N}, \mathrm{p}<0.05)$ and $\mathrm{S}(0 \mathrm{ppm} 62.23 \pm 7.70 \mathrm{~N}, 50 \mathrm{ppm} 45.92$ $\pm 12.01 \mathrm{~N}, \mathrm{p}<0.05)$. B6 showed a significant decrease in $\mathrm{F}_{\mathrm{u}}(0 \mathrm{ppm} 23.62 \pm 5.40 \mathrm{~N}, 50 \mathrm{ppm} 15.84 \pm 5.12 \mathrm{~N}, \mathrm{p}<$ $0.05)$ and displacement at failure (0 ppm $0.72 \pm 0.12 \mathrm{~mm}$, $50 \mathrm{ppm} 0.54 \pm 0.10 \mathrm{~mm}, \mathrm{p}<0.05)$. A/J significantly decreased in $S(0$ ppm $50.37 \pm 19.91 \mathrm{~N} / \mathrm{mm}, 50$ ppm 29.09 $\pm 5.57 \mathrm{~N} / \mathrm{mm}, \mathrm{p}<0.05)$ and there was a trend towards a decrease in $\mathrm{F}_{\mathrm{u}}(0 \mathrm{ppm} 19.12 \pm 5.38 \mathrm{~N}, 50 \mathrm{ppm} 13.5 \pm$ $2.25 \mathrm{~N}, 0.05<\mathrm{p}<0.1)$. BALB showed a significant decrease in $\mathrm{F}_{\mathrm{u}}(0 \mathrm{ppm} 25.17 \pm 5.41 \mathrm{~N}, 50 \mathrm{ppm} 18.34 \pm$ $4.21 \mathrm{~N}, \mathrm{p}<0.05)$, and $129 \mathrm{~S} 1$ experienced a significant decrease in $\mathrm{F}_{\mathrm{u}}(0$ ppm $39.64 \pm 4.24 \mathrm{~N}, 50$ ppm $30.47 \pm$ $5.20 \mathrm{~N}, \mathrm{p}<0.05)$. The material properties of the vertebrae changed significantly yet variably in $129 \mathrm{~S} 1, \mathrm{FVB}, \mathrm{B} 6$, and $\mathrm{A} / \mathrm{J}$. The US decreased in $129 \mathrm{~S} 1(0 \mathrm{ppm} 17.30 \pm 1.73 \mathrm{MPa}$, $50 \mathrm{ppm} 13.20 \pm 2.22 \mathrm{MPa}, \mathrm{p}<0.05), \mathrm{B} 6$ (0 ppm $10.94 \pm$ $2.61 \mathrm{MPa}, 50 \mathrm{ppm} 6.29 \pm 2.97 \mathrm{MPa}, \mathrm{p}<0.05)$, and $\mathrm{A} / \mathrm{J}$ $(0 \mathrm{ppm} 10.53 \pm 3.45 \mathrm{MPa}, 50 \mathrm{ppm} 7.46 \pm 0.78 \mathrm{MPa}, \mathrm{p}<$ 0.05). E (0 ppm $102.50 \pm 14.17 \mathrm{MPa}, 50 \mathrm{ppm} 70.45 \pm$ $20.45 \mathrm{MPa}, \mathrm{p}<0.05)$ and toughness $(0 \mathrm{ppm} 1.49 \pm 0.20$ $\left.\mathrm{mJ} / \mathrm{mm}^{3}, 50 \mathrm{ppm} 0.98 \pm 0.49 \mathrm{~mJ} / \mathrm{mm}^{3}, \mathrm{p}<0.05\right) \mathrm{de}-$ creased in FVB ( $<$ <0.05), and E (0 ppm $103.69 \pm 51.22$ $\mathrm{MPa}, 50 \mathrm{ppm} 13.20 \pm 2.22 \mathrm{MPa}, \mathrm{p}<0.05)$ decreased in $\mathrm{A} / \mathrm{J}(\mathrm{p}<0.05)$. No significant difference was observed in geometrical parameters due to $50-\mathrm{ppm} \mathrm{F}$ exposure in any of the strains. Some correlations were observed between some parameters and F, but no fixed pattern could be followed. In the AKR strain, trabecular BMD showed significant correlation to the accumulation of bone $\mathrm{F}$ ( $\mathrm{r}=$ $0.594, p=0.042)$ and serum ALP $(r=0.612, p=0.034)$. In the $\mathrm{C} 3 \mathrm{H}$ strain, trabecular BMD showed significant correlation to DF $(r=0.787, p=0.002)$. Significant correlation to the accumulation of bone $\mathrm{F}$ was observed only in FVB $\left(\mathrm{F}_{\mathrm{u}}: \mathrm{r}=-0.851, \mathrm{p}<0.001 ; \mathrm{S}: \mathrm{r}=-0.612, \mathrm{p}=0.034\right)$, $\mathrm{A} / \mathrm{J}(\mathrm{S}: \mathrm{r}=-0.633, \mathrm{p}=0.049)$, and $129 \mathrm{~S} 1\left(\mathrm{~F}_{\mathrm{u}}: \mathrm{r}=-0.683\right.$, $\mathrm{p}=0.021)$ in mechanical tests of the vertebrae.

\section{Discussion}

Inbred mouse strains provide an opportunity to investigate environmental effects (F) superimposed upon the normal variation between strains for many of the traits examined. Differences in response to $\mathrm{F}$ have been demonstrated in previous studies on mice [Everett et al., 2002; Vieira et al., 2005a; Vieira et al., 2005b; Mousny et al., 2006; Yan et al., 2007]. In the current study, prolonged and continuous $\mathrm{F}$ exposure led to strain-dependent and variable-phenotypic responses involved in dental enamel development, bone metabolism and mechanics, serum F, and bone F. No consistent pattern was observed between DF severity and variations in bone metabolism including chemistries, ex vivo assays, and bone quality parameters. Decreased bone quality was not consistently correlated to F treatment as reduced quality was observed both in the strains with intermediate and high bone $\mathrm{F}$ content and in the strains with low bone F content. Thus, such changes in bone metabolism cannot simply be explained by the effect of bone F content. This indicates that high $\mathrm{F}$ accumulation in bone or serum may not be a predictor of altered bone metabolism. On this basis, we hypothesize that other mechanisms may be involved in bone $\mathrm{F}$ accumulation and its effects on bone metabolism. These may include direct interaction with the bone mineral matrix through a physicochemical mechanism [Grynpas and Omelon, 2007; Chachra et al., 2008] and/or some biological effects of F on bone cells [Farley et al., 1983; Lau and Baylink, 1998; Rodriguez and Rosselot, 2001; Oguro et al., 2003; Mousny et al., 2006; Yan et al., 2007]. DF susceptibility in mice is a complex trait and for at least 2 strains it is associated with genes on 2 chromosomes that likely have additive effects [Everett, 2010]. Multiple interacting loci are likely responsible for observed differences in DF susceptibility among the strains examined in this study. Haplotype association studies would indicate whether there are shared alleles between strains controlling DF susceptibility. Our study showed that treatment durations ( 3 weeks and 60 days) induce different responses regarding $\mathrm{OC}$ in the $\mathrm{C} 3 \mathrm{H}$ strain. Weanling $\mathrm{C} 3 \mathrm{H}$ mice treated with $\mathrm{F}$ for 3 weeks showed a robust induction of osteoclastogenesis (OC) with increases in serum RANKL and iPTH [Yan et al., 2007], whereas adult C3H mice and 60-day treatment did not show the same increase in OC. The responses of young growing mice did not forecast responses of older animals. It is possible that the induction of osteoclastogenesis (without measurable bone loss) seen previously could not be maintained because this high bone mass strain adapted to the $\mathrm{F}$ during the longterm treatment. However, $\mathrm{A} / \mathrm{J}$, another high bone mass strain, demonstrated increases in iPTH, RANKL, and $\mathrm{OC}$ in response to $\mathrm{F}$. We also observed in $\mathrm{A} / \mathrm{J}$ a significant increase in serum $\mathrm{PO}_{4}$ which indicated that the change in PTH might be related to $\mathrm{PO}_{4}$ homeostasis regulation 
since it has been reported that $\mathrm{F}$ may damage kidneys [Chattopadhyay et al., 2010] to induce $\mathrm{PO}_{4}$ retention; furthermore, $\mathrm{PO}_{4}$ retention leads to a chronic increase in PTH secretion [Turner et al., 2010]. This may become the initial causative factor inducing $\mathrm{OC}$ in bone via the $\mathrm{PTH}$ pathway due to $\mathrm{F}$ exposure. We also noticed a small but significant increase in serum $\mathrm{Mg}$ for FVB following F exposure. One previous report demonstrated the increase in serum $\mathrm{Mg}$ following $\mathrm{F}$ exposure and speculated it was due to more efficient absorption from the diet or F producing a bone salt that releases Mg slowly [O'Dell et al., 1973]. However, we did not observe any significant change in bone $\mathrm{Mg}$ content. This might be due to the regulation of the body system to keep mineral homeostasis. Thus, absorption from the diet might be one possible reason for the increased serum Mg. Changes in mechanical properties might be a result of the alterations in the mineral crystal structure due to $\mathrm{F}$ precipitation. Among the strains with decreased cortical bone material properties, $129 \mathrm{~S} 1$ is the only one that demonstrated improved geometry, increased OC, and increased bone formation mark- er ALP, perhaps indicating increased bone remodeling. This evidence of increased cellular action further supports our idea that the effect of $\mathrm{F}$ on bone quality depends on the combination of the direct influence on the bone mineral matrix and biological effects on bone cells. In conclusion, prolonged and continuous $\mathrm{F}$ exposure leads to strain-dependent and variable-phenotypic responses involving dental enamel development and bone metabolism. No predictor of bone fluorosis can be found among $\mathrm{DF}$, bone F content, and serum $\mathrm{F}$. The effect of $\mathrm{F}$ on bone may depend on the combination of the direct influence on the bone mineral matrix and the biological effects on bone cells via hormone(s).

\section{Acknowledgements}

We gratefully acknowledge Ms. Ashley Johnson and Mr. Clay Hamrick for their technical support with the micro-CT. This work was supported by the NIH/NIDCR R01DE014853 (E.T.E.).

\section{References}

Bronckers, A.L., D.M. Lyaruu, P.K. DenBesten (2009) The impact of fluoride on ameloblasts and the mechanisms of enamel fluorosis. J Dent Res 88: 877-893.

Carvalho, J.G., A.L. Leite, D. Yan, E.T. Everett, G.M. Whitford, M.A. Buzalaf (2009) Influence of genetic background on fluoride metabolism in mice. J Dent Res 88: 1054-1058.

Chachra, D., A.P. Vieira, M.D. Grynpas (2008) Fluoride and mineralized tissues. Crit Rev Biomed Eng 36: 183-223.

Chattopadhyay, A., S. Podder, S. Agarwal, S. Bhattacharya (2010) Fluoride-induced histopathology and synthesis of stress protein in liver and kidney of mice. Arch Toxicol, Epub ahead of print

Chou, M.Y., D. Yan, T. Jafarov, E.T. Everett (2009) Modulation of murine bone marrowderived CFU-F and CFU-OB by in vivo bisphosphonate and fluoride treatments. Orthod Craniofac Res 12: 141-147.

Everett, E.T. (2010) Fluoride's effects on the formation of teeth and bones, and the influence of genetics. J Dent Res, E-pub ahead of print.
Everett, E.T., M.A. McHenry, N. Reynolds, H. Eggertsson, J. Sullivan, C. Kantmann, E.A. Martinez-Mier, J.M. Warrick, G.K. Stookey (2002) Dental fluorosis: variability among different inbred mouse strains. J Dent Res 81 : 794-798.

Farley, J.R., J.E. Wergedal, D.J. Baylink (1983) Fluoride directly stimulates proliferation and alkaline phosphatase activity of boneforming cells. Science 222: 330-332.

Grynpas, M.D., S. Omelon (2007) Transient precursor strategy or very small biological apatite crystals? Bone 41: 162-164.

Lau, K.H., D.J. Baylink (1998) Molecular mechanism of action of fluoride on bone cells. J Bone Miner Res 13: 1660-1667.

Mousny, M., X. Banse, L. Wise, E.T. Everett, R. Hancock, R. Vieth, J.P. Devogelaer, M.D. Grynpas (2006) The genetic influence on bone susceptibility to fluoride. Bone 39: 1283-1289.

O’Dell, B.L., R.I. Moroni, W.O. Regan (1973) Interaction of dietary fluoride and magnesium in guinea pigs. J Nutr 103: 841-850.
Oguro, A., T. Kawase, M. Orikasa (2003) NaF induces early differentiation of murine bone marrow cells along the granulocytic pathway but not the monocytic or preosteoclastic pathway in vitro. In Vitro Cell Dev Biol Anim 39: 243-248.

Rodriguez, J.P., G. Rosselot (2001) Sodium fluoride induces changes on proteoglycans synthesized by avian osteoblasts in culture. J Cell Biochem 83: 607-616.

- Turner, R.T., U.T. Iwaniec, K. Marley, J.D. Sibonga (2010) The role of mast cells in parathyroid bone disease. J Bone Miner Res 25: 16371649.

Vieira, A.P., R. Hanocock, H. Eggertsson, E.T. Everett, M.D. Grynpas (2005a) Tooth quality in dental fluorosis genetic and environmental factors. Calcif Tissue Int 76: 17-25.

Vieira, A.P., M. Mousny, R. Maia, R. Hancock, E.T. Everett, M.D. Grynpas (2005b) Assessment of teeth as biomarkers for skeletal fluoride exposure. Osteoporos Int 16: 1576-1582.

Yan, D., A. Gurumurthy, M. Wright, T.W. Pfeiler, E.G. Loboa, E.T. Everett (2007) Genetic background influences fluoride's effects on osteoclastogenesis. Bone 41: 1036-1044. 